\title{
Pengaruh Dukungan Publik, Kelembagaan, Jaringan Sosial, Bisnis, dan Kepribadian Terhadap Kinerja Kewirausahaan
}

\author{
Michelle Monica dan Hannes Widjaja \\ Program Studi Manajemen Fakultas Ekonomi dan Bisnis, Universitas Tarumanagara, \\ Jakarta \\ e-mail:michellemonica97@gmail.com
}

\begin{abstract}
This study aims to determine the effect of Public and Institutional Support, Social and Business Networks, and Personality on Entrepreneurial Performance in West Jakarta. The population in this study were food and beverage entrepreneurs in West Jakarta. The sampling method is done by non-probability sampling technique with purposive sampling. The method of data collection was done by distributing questionnaires to 70 respondents. Data processing uses SPSS version 22. From the test results it is found that social and business networks, and personality on entrepreneurial performance have a positive and significant influence on success in food and beverage entrepreneurship in West Jakarta. Whereas, Public and Institutional Support does not performance have a positive and significant influence partially.
\end{abstract}

Keywords: Institutional, Social Networks, Business, Personality.

Abstrak: Penelitian ini bertujuan untuk mengetahui pengaruh Dukungan Publik dan Kelembagaan, Jaringan Sosial dan Bisnis, dan Kepribadian terhadap Kinerja Kewirausahaan di Jakarta Barat. Populasi dalam penelitian ini adalah wirausahawan/wati makan dan minuman di Jakarta Barat. Metode pengambilan sampel dilakukan dengan teknik non probability sampling dengan purposive sampling. Metode pengumpulan data dilakukan dengan menyebar kuesioner kepada 70 responden. Pengolahan data mengunakan SPSS versi 22. Dari hasil pengujian diperoleh bahwa jaringan sosial dan bisnis, dan kepribadian memiliki pengaruh yang positif dan signifikan terhadap kesuksesan dalam berwirausaha Food\&Beverage di Jakarta Barat. Sedangkan, dukungan publik dan kelembagaan tidak memiliki pengaruh yang positif dan signifikan secara parsial.

Kata Kunci: Kelembagaan, Jaringan Sosial, Bisnis, Kepribadian

\section{PENDAHULUAN}

Era globalisasi sekarang ini sudah tidak dapat dipungkiri lagi bahwa kemajuan perkembangan ekonomi yang terjadi dan kalau dilihat akhir-akhir ini banyak bermunculan usaha-usaha baru, khususnya usaha mikro dan kecil. keadaan ekonomi di Indonesia yang sedang berkembang membuat semakin tingginya tingkat kompetisi usaha yang ada. Dapat dilihat bahwa semakin banyaknya jenis - jenis usaha baru yang bermunculan. Selain itu juga semakin banyaknya jenis usaha baru tentunya juga akan meningkatkan daya saing antar usaha yang ada, sehingga apabila usaha tidak dikelola dengan sebaik - baiknya, maka kinerja kewirausahaanpun akan menjadi tidak maksimal. Oleh sebab itu, kinerja 
kewirausahaan yang baik dalam suatu usaha yang dijalankan merupakan tujuan utama sebuah usaha dijalankan.

Semakin sempitnya lapangan pekerjaan saat ini tentunya peran suatu kewirausahaan sangat penting untuk masyarakat luas untuk mendorong terciptanya lapangan kerja baru. Pentingnya kewirausahaan untuk masyarakat modern telah disorot secara luas oleh Carree dan Thurik (2003). Menurut Praag dan Versloot (2007) beberapa usaha baru mampu memberikan kontribusi yang lebih tinggi untuk penciptaan lapangan kerja dan menghasilkan dan mengkomersialkan inovasi berkualitas tinggi. selain itu ketika berdasarkan inovasi, kegiatan kewirausahaan terbukti terkait secara positif dengan pertumbuhan ekonomi (Acs et al., 2008).

Di satu sisi, diakui bahwa kewirausahaan melibatkan penciptaan bisnis baru (Reynolds et al., 1994), warisan bisnis (Chaganti dan Schneer, 1994) atau pembelian bisnis yang mapan (Cooper dan Dunkelberg, 1986). Di sisi lain, kewirausahaan mungkin terlibat dalam revitalisasi organisasi yang matang dalam menanggapi peluang baru, atau dapat diterapkan dalam konteks yang berbeda, termasuk organisasi nirlaba dan publik (Phan et al., 2009).

Salah satu aspek kewirausahaan yang telah menarik minat khusus adalah faktor penentu keberhasilan usaha baru. Ini adalah topik yang relevan mengingat risiko kegagalan yang tinggi yang dimulai dari awal. Pengusaha dapat mengambil manfaat dari pengetahuan ini baik di tahap pra-peluncuran dan tahap awal dari perusahaan baru. Juga, wawasan tentang faktor-faktor yang memengaruhi kinerja usaha baru dapat sangat berguna bagi pemerintah yang berusaha mengembangkan kebijakan yang efektif tidak hanya untuk mempromosikan tetapi juga untuk mendukung kewirausahaan. Meskipun memprediksi kinerja dan kesuksesan usaha baru mungkin sangat menantang, seperti yang ditunjukkan oleh keragaman hasil penelitian yang dibuat di bidang ini, ini adalah tema yang bermanfaat untuk dikembangkan lebih lanjut, dengan tujuan mengeksplorasi hubungan yang kompleks antara kondisi kewirausahaan dan kinerja dan berkontribusi pada peningkatan klarifikasi daerah tersebut. Namun, konsep kinerja mungkin sulit dipahami. Seperti yang dikemukakan oleh Lumpkin dan Dess (1996, P/. 154), "perusahaan kecil milik pribadi dapat menganggap keberlangsungannya sebagai indikator yang memuaskan dari kinerja tinggi, meskipun tidak dapat mengklaim memiliki pengembalian yang kuat atas aset atau pertumbuhan di pasar". Menyadari bahwa ukuran keuangan mungkin tidak sepenuhnya mewakili indikator kinerja penelitian ini menggunakan langkah-langkah ini dengan tujuan mengurangi subjektivitas konsep kinerja.

Dalam berjalannya waktu, kewirausahaan merupakan suatu hal yang penting untuk disoroti perkembangannya dan jalannya usaha tersebut. pentingnya kewirausahaan telah menarik minat dari pembuat kebijakan / pemerintah dan akademisi. Organisasi untuk Kerjasama Ekonomi dan Pembangunan (OECD, 1998) menekankan peran kewirausahaan dalam mengatasi pengangguran dan kemiskinan, dan dalam meningkatkan tingkat daya saing di berbagai sektor. Demikian pula, Komisi Eropa (2006) mengakui bahwa kewirausahaan dan usaha kecil yang dihasilkan dari itu sangat penting bagi ekonomi Uni Eropa, karena mereka adalah sumber utama pekerjaan, dinamika bisnis dan inovasi. Dari akademik perspektif, minat yang terus meningkat tercermin dalam peningkatan eksponensial dalam jumlah kursus, program, konferensi, jurnal dan pusat penelitian yang didedikasikan untuk daerah tersebut (Cooper, 2003). Maka dari itu semakin banyaknya lembaga - lembaga yang menyadari pentingnya suatu kewirausahaan dapat membuat semakin besarnya dukungan dari lembaga - lembaga dan publik. 
Pada era globalisasi saat ini juga membuat penggunaan media sosial sebagai saluran berbisnis atau mempromosikan bisnis sangat diminati oleh pembisnis. Selain dapat menjangkau pasar yang cukup luas, media sosial dinilai lebih murah jika dibandingkan dengan iklan melalui majalah, surat kabar, televise, ataupun radio. Jaringan sosial dan bisnis juga memainkan peran penting dalam proses kewirausahaan (Jenssen dan Koenig, 2002). Meskipun tautan ini dapat berubah dan memiliki peran dan kepentingan yang berbeda pada tahap yang berbeda dalam kehidupan usaha baru (Greve dan Salaff, 2003), penelitian menunjukkan bahwa jaringan dan jaringan selalu menjadi alat kewirausahaan penting yang berkontribusi pada pembentukan, pengembangan, dan pertumbuhan perusahaan kecil (Salavisa et al., 2009). Jaringan ini terbukti penting terutama untuk perusahaan teknologi tinggi yang menghadapi tingkat ketidakpastian yang lebih tinggi dan memiliki lebih banyak interdependensi yang menuntut hubungan yang dibangun berdasarkan kepercayaan (Moensted, 2007).

Lebih lanjut, wirausahawan mungkin tertarik pada lingkungan di mana sumber daya dan sistem informasi bersama mendorong pembentukan dan pengembangan perusahaan (Westhead dan Bastone, 1999, 1998). Penelitian mempresentasikan bukti hubungan positif antara jejaring sosial pengusaha dengan keberhasilan dan kinerja keuangan mereka (Baron dan Markman, 2003). Selain itu, ditemukan bahwa jaringan yang lebih berkembang, dalam hal jumlah dan kualitas ikatan lebih bermanfaat untuk memulai daripada jaringan yang kurang berkembang (Larson dan Starr, 1993). pengusaha tertanam dalam jaringan hubungan sosial yang memungkinkan mereka untuk memperluas pengetahuan mereka tentang peluang, berbagai tindakan, kemampuan untuk mendapatkan akses ke sumber daya penting (misalnya pelanggan, pemasok, keuangan, tempat, dll.) Dan untuk mendapatkan pengetahuan (Floyd dan Wooldridge, 1999) yang memungkinkan mereka untuk menghindari dan / atau menghadapi hambatan pengembangan bisnis (Aldrich dan Elam, 1997). Menurut Granovetter (1985) ada semacam keleluasaan bisnis kecil dalam konteks sosial yang lebih luas yang menggabungkan jaringan dan hubungan keluarga.

Salah satu aliran penelitian tentang kewirausahaan didasarkan pada gagasan bahwa pengusaha menunjukkan beberapa karakteristik atau, setidaknya, kompetensi yang berkontribusi pada kecenderungannya untuk menciptakan usaha baru atau memulai dan memengaruhi kesuksesannya (Veciana et al., 2005). Dipercaya bahwa beberapa karakteristik pribadi memengaruhi kesuksesan wirausaha, Oleh karena itu penting untuk mengungkap kualitas - kualitas ini yang memungkinkan wirausahawan untuk berpikir dan bertindak dengan cara yang secara positif mempengaruhi hasil dari usaha mereka. kebutuhan untuk pencapaian diri, kreativitas dan inisiatif, kecenderungan risiko, kepercayaan diri dan lokus kontrol, kemandirian dan otonomi, motivasi energi dan komitmen, ketekunan, nilainilai dan sikap, dan tujuan pribadi (Gorman, 1997).

Karakteristik ini dapat bervariasi dalam kepentingannya. Misalnya, menurut Robinson et al. (1991) mengakui bahwa harga diri dan inovasi lebih relevan daripada kebutuhan untuk pencapaian diri. Pada gilirannya, Davidsson (1989) menyimpulkan bahwa kebutuhan akan pencapaian bukan merupakan penjelasan yang relevan untuk perilaku kewirausahaan, karena konsep tersebut kurang presisi dan karena itu sulit untuk diukur. Mengenai kecenderungan risiko, meskipun ini merupakan kondisi penting untuk menjalani proyekproyek baru dan berinovasi, sebagian besar studi empiris menunjukkan bahwa ini tidak sebanyak ciri pengusaha (Davidsson, 1989) karena merupakan variabel situasional. Beberapa penelitian mengusulkan bahwa pengambilan risiko sangat tergantung pada 
persepsi situasi (Hogarth, 1987) atau persepsi oleh pembuat keputusan sendiri sebagai ahli di lapangan (Heath dan Tversky, 1991).

Salah satu kritikus utama dari pendekatan ini adalah Gartner (1989). Dia berpikir bahwa jika semua ciri yang muncul dari studi tentang tema itu disusun menjadi satu profil psikologis, ini akan menghasilkan gambaran dengan kontradiksi yang jelas dan sangat umum sehingga hampir semua orang dapat dimasukkan ke dalamnya. Gartner (1989) menegaskan bahwa satu-satunya karakteristik yang memisahkan pengusaha dari bagian dunia lainnya adalah kenyataan bahwa yang pertama menciptakan perusahaan dan yang lain tidak. Dia melihat kewirausahaan sebagai perilaku yang bertentangan dengan profil tertentu. Namun demikian, wirausahawan adalah bagian dari konsep kewirausahaan, karena proses wirausaha merupakan hasil dari seseorang, dari kemampuannya untuk menciptakan atau mengenali peluang dan dari tindakannya untuk mengevaluasi dan menjelajahinya (Shane dan Venkataraman, 2000).

Jadi, penelitian tentang wirausahawan masih berjalan, meskipun tidak terlalu berorientasi pada pencarian kualitas penentunya, karena untuk mengungkapkan cara dia berpikir dan bertindak. Pendekatan ini tertarik untuk mengetahuibagaimana wirausahawan berpikir dan membuat keputusan, yaitu memahami kognisi kewirausahaan. Mitchell et al. (2002, P/. 97) mendefinisikan kognisi kewirausahaan sebagai "struktur pengetahuan yang digunakan orang untuk membuat penilaian, penilaian, atau keputusan yang melibatkan evaluasi peluang, penciptaan usaha, dan pertumbuhan. Wawasan kewirausahaan adalah tentang memahami bagaimana wirausahawan menggunakan penyederhanaan model mental untuk mengumpulkan informasi yang sebelumnya tidak terhubung yang membantu mereka untuk mengidentifikasi dan menciptakan produk atau layanan baru dan untuk mengumpulkan sumber daya yang diperlukan untuk memulai dan mengembangkan bisnis".

\section{KAJIAN TEORI}

Dukungan Publik dan Kelembagaan. Gilbert et al. (2004) berpendapat: "kebijakankewirausahaan, pada kenyataannya, muncul sebagai salah satu instrumen kunci untuk membuka kunci pertumbuhan ekonomi." Shane (2009) menyatakan: "tidak semua proyek kewirausahaan harus didorong oleh pemerintah jika pertumbuhan ekonomi harus dikejar." Menurut James (2009): Pelaku bisnis membutuhkan pelaku politik dan sebaliknya, karena pemerintah memiliki peran sebagai lembaga yang berwenang dalam membuat segala peraturanyang berhubungan dengan bisnis. Contoh, pajak perusahaan yang ditetapkan oleh pemerintah harus mempertimbangkan apa yang akan didapatkan oleh pemerintah maupun perusahaan itu sendiri. Berdasarkan beberapa hal yang telah diuraikan, kesimpulan yang didapatkan yaitu dukungan publik dan kelembagaan memiliki peranan yang cukup penting dalamkemajuan pertumbuhan ekonomi, dan memiliki hubungan saling membutuhkan yang cukup signifikan.

Jaringan Sosial dan Bisnis. Granovetter dan Swedberg (1992) menyatakan: "Jaringan sosial adalah suatu rangkaian hubungan yang teratur atau hubungan sosial yang sama antara individu-individu atau kelompok-kelompok." Kusnadi (1998) menyatakan: "Setiap individu memiliki kemampuan yang berbeda dalam hal kuantitas dan kualitas atau intensitas hubungan-hubungan sosial yang dilakukannya, sekalipun dalam kehidupan masyarakat terbuka luas peluang bagi individu untuk melakukan hubungan sosial secara maksimal. Hubungan-hubungan tersebut tidak hanya melibatkan dua individu, tetapi juga banyak 
individu. Keterhubungan antarindividu-individu tersebut akan membentuk suatu jaringan sosial yang sekaligus merefleksikan terjadinya pengelompokan sosial dalam kehidupan masyarakat." Agusyanto (2007) mengatakan: "Hubungan sosial atau saling keterhubungan merupakan interaksi sosial yang berkelanjutan (relatif cukup lama atau permanen) yang terakhirnya diantara mereka terikat satu sama lain dengan atau oleh seperangkat harapan yang relatif stabil." Setelah melihat uraian di atas, maka dapat disimpulkan jaringan sosial dan bisnis berpengaruh dalam menjalin hubungan antarindividu maupun antarkelompok. Serta dapat membantu pelaku bisnis menjalin hubungan bisnis yang baik dengan sesama wirausahawan atau rekan bisnis maupun hubungan dengan konsumen.

Kepribadian. Menurut Dorland (2002): "kepribadian merupakan pola khas seseorang dalam berfikir, merasakan dan berprilaku yang relative stabil dan dapat diperkirakan." Menurut Mastuti (2005): "kepribadian adalah sebuah karakteristik didalam diri individu yang relatif menetap, bertahan, yang mempengaruhi penyesuaian diri individu terhadap lingkungan." Menurut Agus Sujanto et al. (2014): "kepribadian adalah suatu totalitas psikofisis yang kompleks dari individu, sehingga nampak dalam tingkah lakunya yang unik." Dari pendapat para ahli tentang kepribadian yang telah dijabarkan, ditarik kesimpulan yaitu kepribadian adalah cara seseorang bereaksi dan melakukan interaksi dengan orang lain.

Kinerja. MenurutWheelen dan Hunger (2010): "Kinerja bisnis selain sebagai cerminan dari kesuksesan atau kegagalan suatu perusahaan, dapat juga menggambarkan hasil pencapaian perusahaan dari serangkaian pekerjaan atau kegiatan dalam periode tertentu."

Menurut Wu dan Zhao(2009): Kinerja adalah "performance means how well the organization is managed and the value the organization delivers for customers and other stakeholders." Menurut Latinen (2002): "kinerja dapat diskripsikan sebagai kemampuan suatu objek untuk menghasilkan return dalam dimensi yang ditentukan sebelumnya, dalam kaitannya dengan target." Berdasarkan definisi tentang kinerja di atas, maka kinerja adalah hasil pekerjaan dari suatu usaha, hasil pekerjaan tersebut tidak selalu baik namun bisa juga hasilnya tidak baik. Jadi kinerja bisa dikatakan sebagai penilaian berjalan atau tidak, meningkat atau menurunnya sebuah pekerjaan dalam kurun waktu tertentu.

Hipotesis. Setelah melihat uraian - uraian yang telah disusun di atas yaitu hubungan dan pengaruh antar variabel - variabel dan kerangka pemikiran yang disebutkan dalam penelitian ini, sehingga dapat disebutkan hipotesis dalam penelitian ini.

$\mathrm{H}_{1}$ : Terdapat pengaruh Dukungan Publik dan Kelembagaan terhadap Kinerja

Kewirausahaan pada wirausahawan didaerah Jakarta Barat.

$\mathrm{H}_{2}$ : Terdapat pengaruh Jaringan Sosial dan Bisnis terhadap Kinerja Kewirausahaan pada wirausahawan didaerah Jakarta Barat.

$\mathrm{H}_{3}$ : Terdapat pengaruh Kepribadian terhadap Kinerja Kewirausahaan pada wirausahawan didaerah Jakarta Barat. 
Gambar 1. Kerangka Pemikiran

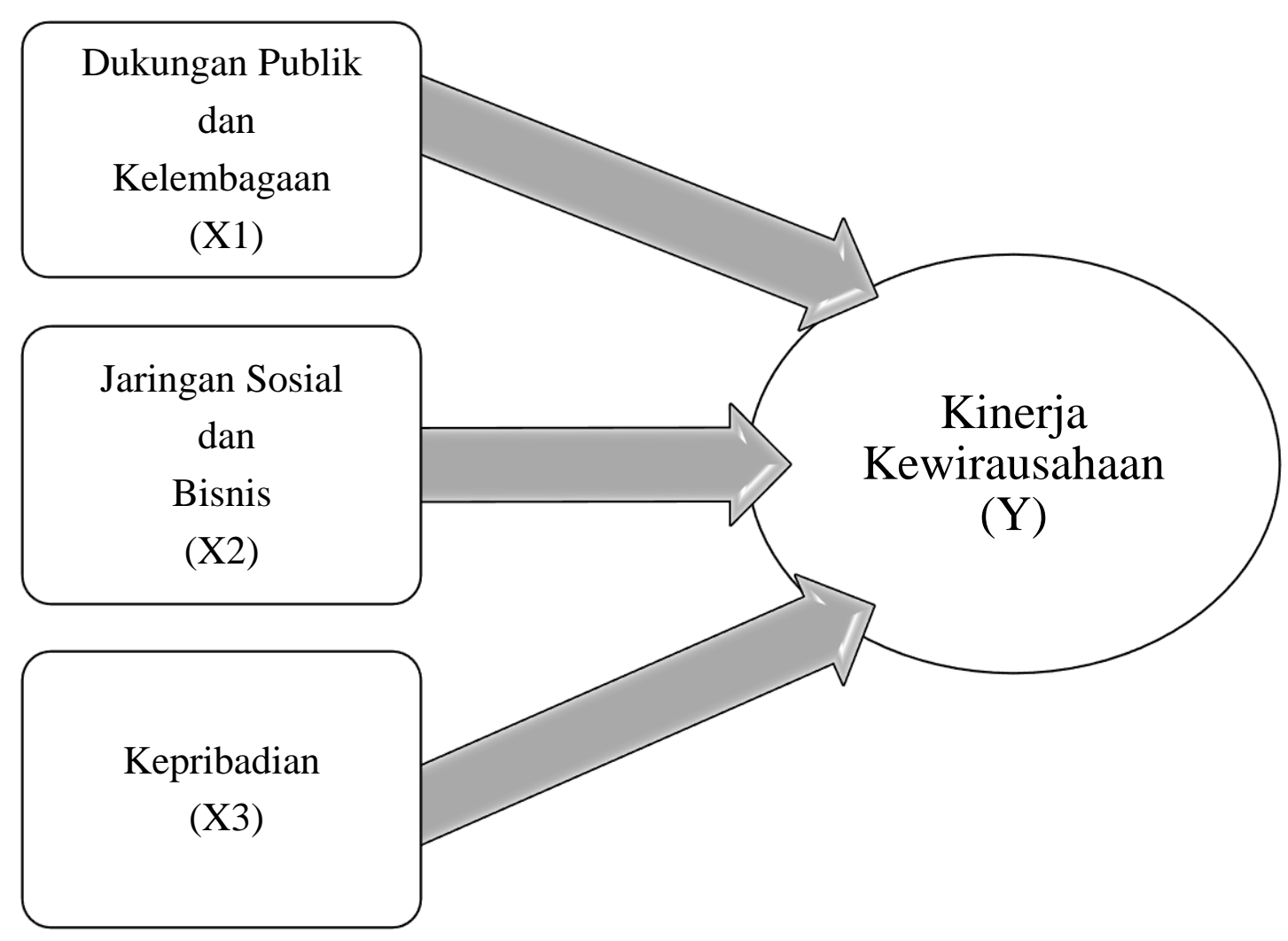

\section{METODELOGI}

Waktu dan Tempat Peneltian. Penelitian ini dilakukan selama empat bulan sejak Februari 2019 hingga Juni 2019 disekitar Jakarta Barat dengan jumlah sampel sebanyak tujuh puluh responden wirausahawan/wati dalam bidang makanan atau minuman.

Desain Penelitian. Malhotra (2007) menyatakan bahwa desain penelitian adalah kerangka kerja yang dapat dipakai untuk menjalankan riset pemasaran. Desain penelitian menyediakan strategi untuk menghasilkan informasi yang dibutuhkan agar masalah dalam penelitian dapatdisusun atau diselesaikan. Dasar dalam melakukan penelitian adalah desain penelitian itu sendiri. Karena itulah, sebuah desain penelitian akan disebut baik apabila penelitian yang dihasilkannya efektif dan efisien. Desain penelitian ini terbagi jadi dua keterangan yaitu eksploratif dan konklusif. Desain penelitian konklusif juga terbagi menjadi dua penjelasan yaitu deskriptif dan kasual. Namun, jenis penelitian yang akan digunakan dalam penelitian ini adalah penelitian deskriptif. Menurut Sugiyono (2009) "Metode penelitian deskriptif adalah penelitian yang dilakukan untuk mengetahui variabel, baik satu variabel atau lebih tanpa membuat perbandingan atau menghubungkan antara variabel satu dengan variabel lainnya."

Skala Pengukuran Variabel. Pengukuran variabel dalam penelitian inimenggunakan skala Likert. Pengumpulan data dilakukan dengan wawancara melalui kuesioner dengan 
menjawab pertanyaan - pertanyaan dengan menggunakan skala Likert sebagai berikut : Skor 1 untuk jawaban sangat tidak setuju, Skor 2 untuk jawaban tidak setuju, Skor 3 untuk jawaban netral, Skor 4 untuk jawaban setuju, Skor 5 untuk jawaban sangat setuju.

Populasi dan Sampel Penelitian. Populasi yang diambil dari penelitian ini adalah para wirausahawan khususnya dalam bidang Food\&Beverage di wilayah Jakarta Barat. Sampel yang digunakan dalam penelitian ini adalah Non-Probability Sampling. Menurut Sugiyono (2001), Non - Probability Sampling adalah teknik yang tidak memberi peluang atau kesempatan yang sama kepada setiap unsur juga anggota populasi untuk dapat dipilih menjadi sampel. Teknik pengambilan sampel dalam penelitian ini menggunakan purposive random sampling yaitu peneliti memiliki syarat khusus dalam pemilihan sampel yang digunakan. Syarat - syarat yang digunakan adalah sebagai berikut: Memiliki usaha yang aktif saat ini, Usaha yang dimiliki beroperasi di Jakarta Barat, Usaha yang dijalankan dalam bidang Food\&Beverage.

Metode Pengumpulan Data. Dalam penelitian ini teknik pengumpulan data yang digunakan yaitu dengan penelitian lapangan (Field Research) dengan melakukan penyebaran kuesioner. Jenis data yang digunakan adalah data primer dari pengisian kuesioner. Teknik analisis data dalam penelitian ini adalah analisis regresi linier berganda dengan menggunakan program SPSS version 22.0 for windows.

\section{HASIL DAN PEMBAHASAN}

Hasil Uji Hipotesis dan Analisis Data. Analisis yang digunakan untuk pengujian hipotesis dalam penelitian ini terbagi menjadi uji validitas, uji reliabilitas, uji asumsi klasik, analisis regresi ganda, uji hipotesis.

Hasil Uji Validitas. Syarat yang digunakanagar dapat dikatakan memenuhi syarat adalah jika $\mathrm{r} \geq 0.3$, maka pertanyaan tersebut dapat dikatakan valid. Apabila $\mathrm{r} \leq 0.3$, maka pertanyaan tersebut dapat dikatakan tidak valid. Hasil uji semua variabel melebihii 0.3 maka dapat ditarik kesimpulan semua variabel memenuhi syarat.

Hasil Uji Reliabilitas (Cronbarch's Alpha). Hasil uji reliabilitas dalam penelitian ini diketahui bahwa, seluruh hasil Cronbach's Alpha dari setiap pernyataan untuk variabel dukungan publik dan kelembagaan, jaringan sosial dan bisnis, kepribadian, dan kinerja kewirausahaan melebihi 0.6, Maka, dapat disimpulkan bahwa seluruh variabel yang digunakan dalam penelitian ini telah reliabel.

Uji Asumsi Klasik. Uji asumsi klasik ini memiliki tiga pengujian yaitu Uji Normalitas, Uji Multikolinieritas, Uji Heteroskedastisitas. Jika semuanya berjalan sesuai rencana maka akan baik - baik saja.

Hasil Uji F. Setelah melihat hasil output spss dari table ANOVA yaitu Fhitung $(49,024)$ lebih besar dari Ftabel $(2,74)$ dan juga nilai sig hitung $(0,000)$, maka dapat disimpulkan variabel dukungan publik dan kelembagaan, jaringan sosial dan bisnis, dan kepribadian secara simultan berpengaruh terhadap kinerja kewirausahaan. 
Hasil Pengujian Signifikansi Dengan Uji T. Hasil pengujian uji t adalah sebagai berikut:

1. Nilai T hitung $(-1,378)<\mathrm{T}$ tabel $(1,998)$ dan nilai sig $(0,173)$ lebih besar dari 0,05 , maka kesimpulan yang didapat yaitu $\mathrm{H} 1$ ditolak yang artinya dukungan publik dan kelembagaan tidak memiliki pengaruh terhadap kinerja kewirausahaan.

2. Nilai T hitung $(3,817)>\mathrm{T}$ tabel $(1,998)$ dan nilai sig $(0,000)$ lebih kecil dari 0,05 , maka kesimpulan yang didapat yaitu $\mathrm{H} 2$ diterima yang artinya jaringan sosial dan bisnis memiliki pengaruh terhadap kinerja kewirausahaan.

3. Nilai T hitung $(7,003)>\mathrm{T}$ tabel $(1,998)$ dan nilai sig $(0,000)$ lebih kecil dari 0,05 , maka kesimpulan yang didapat yaitu $\mathrm{H} 3$ diterima yang artinya kepribadian memiliki pengaruh terhadap kinerja kewirausahaan.

Hasil Uji Analisis Regresi Ganda. Hasil yang didapatkan dari output spss guna menjawab persamaan regresi ganda adalah $\mathrm{Y}=5,901-0,106 \mathrm{D}+0,566 \mathrm{~J}+0,752 \mathrm{~K}+$ e. Nilai RSquare yang diperoleh yaitu sebesar 0,690 atau 69\% yang dimana memiliki pengertian yaitu variabel kinerja kewirausahaan sebesar 69\% mampu dijelaskan oleh variabel dukungan publik dan kelembagaan, jaringan sosial dan bisnis, dan kepribadian dan sisanya dapat dijelaskan oleh variabel-variabel lainnya.

Pengaruh Dukungan Publik dan Kelembagaan terhadap Kinerja Kewirausahaan. Salah satu faktor pendukung kinerja kewirausahaan adalah dukungan publik dan kelembagaan Dukungan ini sangat diperlukan oleh para wirausahawan dalam menjalankan bisnisnya. Mereka membutuhkan tanggapan dari konsumen atau masyarakat sekitar baik secara verbal maupun non - verbal. Selain itu, dukungan dari kelembagaanpun diperlukan, misalnya: dukungan pemerintah yaitu mengatur tentang hukum yang mengatur kewirausahaan. menjamin sistem pasar berjalan dengan baik. lembaga yang mengatur hak dan kewajiban seorang wirausahawan.

Pengaruh Jaringan Sosial dan Bisnis terhadap Kinerja Kewirausahaan. Seperti yang telah dijelaskan sebelumnya tentang jaringan sosial dan bisnis, maka dapat dipahami bahwa jaringan sosial dan bisnis memiliki pengaruh terhadap kinerja kewirausahaan karena dalam sebuah bisnis maupun usaha memerlukan orang laindalam prosesnya baik itu pembeli, pemasok, ataupun orang yang memiliki keahlian dibidangnya. Adanya jaringan sosial dapat membantu wirausahawan dalam menemukan pembeli, pemasok, ataupun orang yang memiliki keahlian dibidangnya tersebut.

Pengaruh Kepribadian terhadap Kinerja Kewirausahaan. Kepribadian adalah karakteristik yang sering muncul dan mendeskripsikan perilaku seorang individu. Kepribadian dapat digunakan sebagai alat paling standar untuk memprediksi hubungan dengan kinerja yang ada. Kepribadian dapat dimengerti melalui BIG FIVE PERSONALITY, ini juga mampu menggambarkan karakteristik dengan nilai tertinggi dan nilai terendah. Faktor - faktor dari lima faktor kepribadian yang ada adalah ekstraversi, kesepakatan, ketelitian, neurotisme, dan keterbukaan atas pengalaman. Sudah nyata terbukti memiliki pengaruh terhadap kinerja untuk tingkat pekerjaan - pekerjaan tertentu. Sehingga kepribadian memiliki pengaruh yang cukup berarti terhadap kinerja, baik dalam perilaku ataupun hasil. 


\section{KESIMPULAN}

Berdasarkan hasil analisis yang telah diuraikan, maka dapat disimpulkan sebagai berikut:

1. Dukungan Publik dan Kelembagaan tidak memiliki berpengaruh terhadap Kinerja kewirausahaan.

2. Jaringan sosial dan bisnis, memiliki pengaruh terhadap Kinerja Kewirausahaan.

3. Kepribadian, memiliki pengaruh terhadap Kinerja Kewirausahaan.

Implikasi. Sebagai implikasi dari penelitian ini disarankan perlu dilakukan penelitian lebih lanjut terhadap variabel - variabel tersebut dan variabel - variabel lainnya yang belum diamati dalam penelitian ini secara kontinyu agar bisa dimanfaatkan oleh kebijakan di Universitas Tarumanagara.

\section{DAFTAR PUSTAKA}

Agus, S., Halem, L., \& Taufik, H. (2014). Psikologi Kepribadian. (Jakarta: Bumi Aksara). Agusyanto, Ruddy. (2007). Jaringan Sosial dalam Organisasi.Jakarta: Raja Grafindo Persada.

Aldrich, H. and Elam, A.B. (1997). "A guide to surfing the social networks", in Birley, S. and Muzyka, D.F. (Eds), Mastering Enterprise, Pitman Publishing, London, pp. 143148.

Baron, R.A. and Markman, G.D. (2003). "Beyond social capital: the role of entrepreneurs' social competence in their financial success", Journal of Business Venturing, Vol. 18 No. 1, pp.41-60.

Carree, M.A. and Thurik, A.R. (2003). "The impact of entrepreneurship on economic growth", in Acs, Z.J. and Audresch, D.B. (Eds), Handbook of Entrepreneurship Research, Kluwer Academic Publishers, Dordrecht, pp. 435-471.

Chaganti, R. and Schneer, J.A. (1994). "A study of the impact of owner's mode of entry on venture performance and management patterns", Journal of Business Venturing, Vol. 9 No. 3, pp. 243-260.

Cooper, A.C. (2003). "Entrepreneurship: the past, the present, the future", in Acs, Z.J. and Audresch, D.B. (Eds), Handbook of Entrepreneurship Research, Kluwer Academic Publishers, Dordrecht, pp. 21-53.

Cooper, A.C. and Dunkelberg, W.C. (1986). "Entrepreneurship and paths to business ownership", Strategic Management Journal, Vol. 7 No. 1, pp. 53-68. Phan, P.H., Wright, M., Ucbasaran, D. and Tan, W.-L. (2009). "Corporate entrepreneurship: current research and future directions", Journal of Business Venturing, Vol. 24 No. 3, pp. 197-205.

Davidsson, P. (1989). Continued Entrepreneurship and Small Firm Growth, Stockholm School of Economics, Stockholm.

Dorland, WAN. (2002). Kamus Kedokteran Dorland. Edisi 29. Jakarta: ECG. 
Floyd, S.W. and Wooldridge, B. (1999). "Knowledge creation and social networks in corporate entrepreneurship: the renewal of organization capability", Entrepreneurship Theory and Practice, Vol. 23 No. 3, pp. 123-143.

Gartner, W.B. (1989). "Who is an entrepreneur? Is the wrong question", American Journal of Small Business, Vol. 12 No. 4, pp.11-32.

Gilbert, B.A., Audretsch, D.B. and McDougall, P.P. (2004). "The emergence of entrepreneurship policy", Small Business Economics, Vol. 22 Nos 3-4, pp. 313 - 323.

Gorman, G. (1997). "Some research perspectives on entrepreneurship education enterprise education and education for small business management: a ten-year literature review", International Small Business Journal, Vol. 15 No. 3, pp. 56-77.

Granovetter, M. (1985). "Economic action and social structure: the problem of embeddedness", American Journal of Sociology, Vol. 91 No. 3, pp. 481-510.

Greve, A. and Salaff, J.W. (2003). "Social networks and entrepreneurship", Entrepreneurship Theory and Practice, Vol. 28 No. 1, pp. 1-22.

Heath, C. and Tversky, A. (1991). "Preference and belief: ambiguity and competence in choice under uncertainty", Journal of Risk and Uncertainty, Vol. 4 No. 1, pp. 5-28.

Hogarth, R. (1987). Judgment and Choice: The Psychology of Decision, John Wiley and Sons, Chichester.

James, R.S. (2009). "Beberapa Keterkaitan Antara Politik dan Bisnis", Jurnal Administrasi Bisnis, vol.5, no.2: hal. 146-159, (ISSN:0216-1249).

Jenssen, J.I. and Koenig, H.F. (2002). "The effect of social networks on resource access and business start-ups", European Planning Studies, Vol. 10 No. 8, pp. 1039 - 1046.

Kusnadi (1998). "Jaringan Sosial Sebagai Strategi Adaptasi Masyarakat Nelayan (studi kasus di desa Pesisir kecamatan Besuki kabupaten Situbondo JATIM)". Tesis Pusat Pengembangan Penelitian Ilmu-ilmu Sosial UI.

Larson, A. and Starr, J.A. (1993). "A network model of organization formation", Entrepreneurship Theory and Practice, Vol. 17 No. 2, pp. 5-15.

Latinen, E. K., (2002). A Dynamic Performance Measurement System: Evidence from Small Finnish Technology Companies. Scandinavian Journal of Management, 18(2), 65-99.

Lumpkin, G. and Dess, G. (1996). "Clarifying the entrepreneurial orientation construct and linking it to performance", Academy of Management Review, Vol. 21 No. 1, pp. 135172.

Malhotra. (2007). Marketing Research An Applied Orientation. International Edition: Pearson

Mastuti, Endah. (2005). Analisis Faktor Alat Ukur Kepribadian Big Five pada Mahasiswa Suku Jawa. Surabaya: Universitas Airlangga.

Mitchell, R.K., Busenitz, L., Lant, T., McDougall, P.P., Morse, E.A. and Smith, J.B. (2002). "Toward a theory of entrepreneurial cognition: rethinking the people side of entrepreneurship research", Entrepreneurship: Theory and Practice, Vol. 27, No. 2, pp. 93-104.

Moensted, M. (2007). "Strategic networking in small high tech firms", International Entrepreneurship and Management Journal, Vol. 3 No. 1, pp. 15-27. Westhead, P. and Bastone, S. (1998). "Independent technology-based firms: the perceived added value of a science park location”, Urban Studies, Vol. 35 No. 12, pp. 2197-2219.

OECD (1998). Fostering Entrepreneurship, OECD, Organization for Economic Co operation and Development, Paris. 
Praag, C. and Versloot, P. (2007). "What is the value of entrepreneurship? A review of recent research", Small Business Economy, Vol. 29 No. 4, pp. 351-382. Acs, Z.J., Desai, S. and Hessels, J. (2008). "Entrepreneurship, economic development and institutions", Small Business Economy, Vol. 31 No. 3, pp. 219 -234.

Reynolds, P., Storey, D.J. and Westhead, P. (1994). "Cross-national comparisons of the variation in new firm formation rates", Regional Studies, Vol. 28 No. 4, pp. 443-456.

Robinson, P.B., Stimpson, D.V., Huefner, J.C. and Hunt, H.K. (1991). “An attitude approach to the prediction of entrepreneurship", Entrepreneurship Theory and Practice, Vol. 15 No. 4, pp. 13-31.

Salavisa, I., Videia, P. and Santos, F. (2009). "Entrepreneurship and social networks in IT sectors: the case of the software industry in Portugal", Journal of Innovation Economics, Vol. 2 No. 2, pp. 15-39.

Shane, S. (2009). "Why encouraging more people to become entrepreneurs is bad public policy", Small Business Economy, Vol. 33 No. 2, pp. 141-149.

Shane, S. and Venkataraman, S. (2000). "The promise of entrepreneurship as a field of research", Academy of Management Review, Vol. 25 No. 1, pp. 217-226.

Sugiyono. (2009). Metode Penelitian Kuantitatif, Kualitatif dan R\&D. Bandung: Alfabeta.

Veciana, J.M., Aponte, M. and Urbano, D. (2005). "University student's attitudes towards entrepreneurship: a two countries comparison", International Entrepreneurship and Management Journal, Vol. 1 No. 2, pp. 165-182.

Westhead, P. and Bastone, S. (1999). "The perceived benefits of a science park location", Entrepreneurship and Regional Development, Vol. 11 No. 2, pp. 129 -154.

Wheelen, T.L. \& Hunger, J.D. (2010). Strategic Management and Business Policy:Achieving Sustainability, 12th Edition. New Jersey: Pearson Internasional Edition.

Wu, D. \& Zhao, F. (2009). Performance measurement in the SMEs in the information technology industry. In F. Zhao, information technology entrepreneurship, Hershey, USA: Idea Group. 